\title{
Assessment of EFL Learners' Attitude Towards Cooperative Language Learning: Limu Preparatory School, East Wollega Zone in Focus
}

\author{
Zeleke Teshome Lucha*, Fekadu Gemeda and Ketema Jirenya
}

Institute of Language Studies and Journalism, Wollega University, P.O. Box: 395, Nekemte, Ethiopia

\begin{tabular}{|c|c|}
\hline \multirow{16}{*}{ 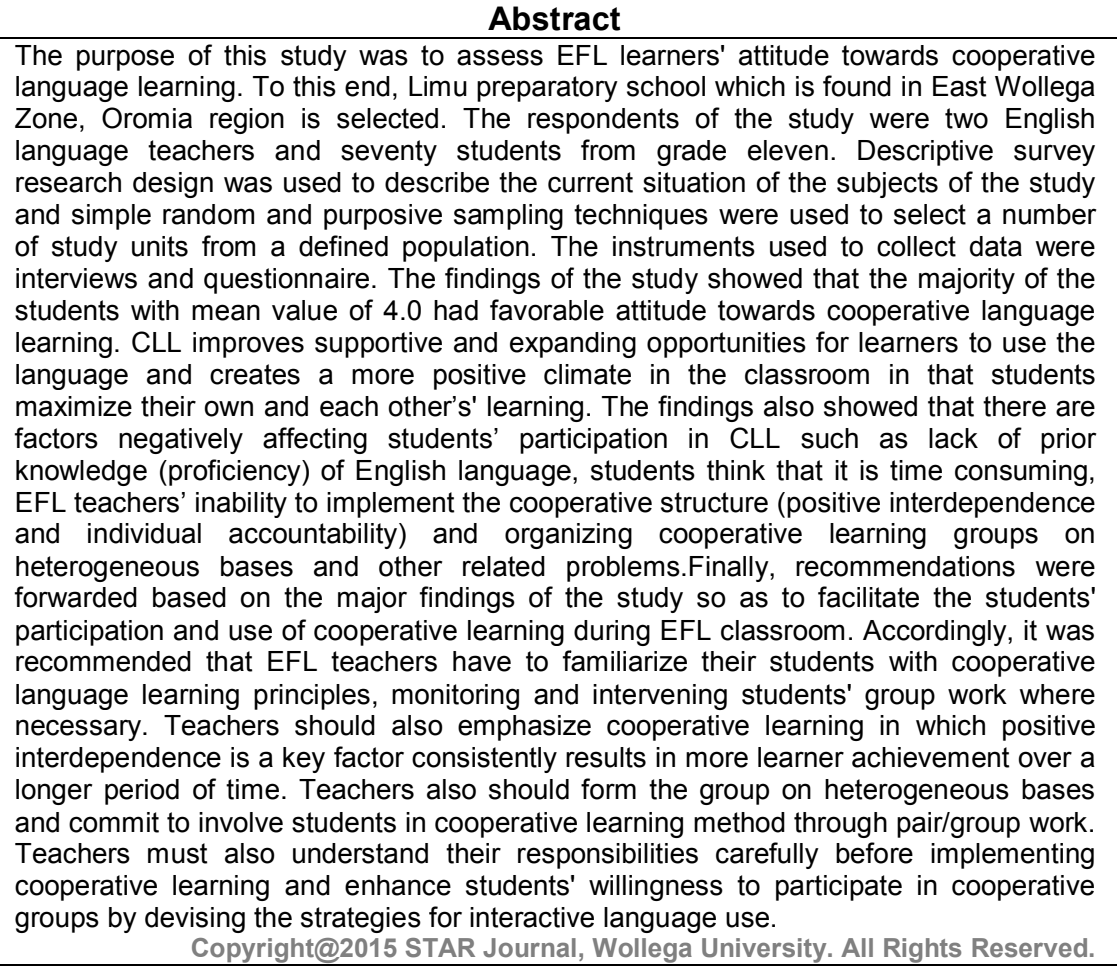 } & \\
\hline & Article History: \\
\hline & Received : 18-06-2015 \\
\hline & Revised : :20-09-2015 \\
\hline & Accepted : 24 \\
\hline & Keywords: \\
\hline & e language learning \\
\hline & Cooperative learning \\
\hline & Attitude \\
\hline & Language learning \\
\hline & EFL teachers \\
\hline & willin \\
\hline & \\
\hline & Zeleke Teshome Lucha \\
\hline & E-mail: \\
\hline & \\
\hline
\end{tabular}

\section{INTRODUCTION}

Cooperation is working together to accomplish shared goals. Within cooperative situations, individuals seek outcomes that are beneficial to themselves and to all other group members. Cooperative learning is the instructional use of small groups so that students work together to maximize their own and each other's learning (Johnson and Johnson, 1999). Johnson and Johnson (1999) state that theorizing on social interdependence began in the early 1900s when the founders of the Gestalt School of Psychology, Koffka (1992), proposed that groups were dynamic wholes in which the interdependence among members could vary. Lewin (1930) refined Koffka's notions stating that the essence of a group is the interdependence among members (created by common goals) which results in the group. For interdependence to be existing, there must be more than one person or entity involvements and the persons or entities must have impact on each other in that a change in the state of one causes a change in the state of the others.

In the late 1940s, one of Lewin's graduate students, Deutsch (1962) extended Lewin's reasoning about social interdependence and formulated a theory of cooperation and competition. Deutsch also conceptualized three types of social interdependence positive, negative and none (Johnson and Johnson, 1999). Positive interdependence tends to result in promotive interaction; negative interdependence tends to result in oppositional interaction, and no interdependence results in an absence of interaction.

Through cooperative learning practice, students get the opportunity to work together with their partners 
Zeleke Teshome Lucha et al.,

towards accomplishing an academic goal. Dornyei (1997) has further stated that although classrooms in which the teacher largely controlled the learning may result in short term learning gains, cooperative learning classrooms in which positive interdependence is a key factor that consistently result in more learner achievement over a long period of time. So, cooperative learning has gained a great emphasis in current language learning methodologies and student's attitude is taken as an integral part of language learning classroom. In line with this, the educational policy of Ethiopia also shares the need of active learning methods in all education levels which is manifested through student-centered approach. Moreover, MOE (2008) has designed a policy to achieve quality of education through active learning strategies such as cooperative learning, problem based learning, and content based learning. Realizing the benefits of cooperative learning, newly used English textbook of grade 11 published in 2003 E.C by Pearson Education Limited has also many group activities in all English language skills.

Many teaching and learning methods have been practiced ranging from the oldest grammar translation method up to the current learner-centered communicative approach (Richards and Rodgers, 2001). Proponents of the current communicative approach such as Richards and Rodgers (2001) suggest that contextualized and meaningful communication is the best possible practice that language learners can engage in as they get opportunities for their own learning through pair/group work activities.

Cooperative learning is one of the methods which enhances motivation and reduce learners' stress and equips them with wider communication strategies through teachers' facilitative role (Brown, 1994). Since interaction between a teacher and students and among students themselves is regarded as a crucial element in language learning, giving considerable attention to classroom interaction in language classrooms is very important. Classroom interaction can be realized through the use of pair and group works in which cooperative learning is mainly manifested in classroom interaction.

In general, different sources such as Richards and Rodgers (2001) recommend that students learn a language best from tasks that involve social interaction as cooperative learning can be an effective method to motivate students, encourage active learning and develop key critical-thinking, communication and decision-making skills. However, from the researchers' experience (in the school), most students are not only reluctant to use English but also unwilling to cooperate during EFL classes. Therefore, it is helpful to study EFL learners' attitude towards cooperative language learning method.

Cooperative learning is a current learning method and nowadays used widely in the world. Different researchers define it in different ways. Cooperative learning has been defined as a strategy which involves students in established and sustained learning groups or teams (King, 1993). Moreover, Kagan (1990) states that CL is a set of processes which help students interact together in order to accomplish a specific goal or develop an end product which is usually content specific. This means teachers design a series of cooperative activities that has a specific content bound for students to finish together.
Sci. Technol. Arts Res. J., July-Sep 2015, 4(3): 240-252

Cooperative learning is a group of learning activity organized so that learning is dependent on the socially structured exchange of information between learners in groups in which each learner is responsible for his/her own learning and is motivated to increase the learning of others through the successful interaction between the group members (Cohen, 1994). Thus, CL is characterized by a set of highly structured and sociologically based techniques that help students work together through free discussion to reach learning goals.

Brown (1994) also describes that $\mathrm{CL}$ in EFL class changed from teacher-centered manipulation of discrete grammatical structure to student - centered acquisition of communicative competence. This is to say that it provides contextualized and meaningful communication whereby students engage in extra language practice with each other. This provides opportunities for authentic communication rather than learning through rote language drills.

The shift in language classroom organization from teacher- fronted to student group work has received a growing amount of theoretical and empirical support as the idea behind cooperative learning allows students to work together to solve problems, and the teacher to facilitate the development of cooperation and teamwork skills. In addition, different researchers and experts in the field of language teaching and learning have considered that there are a number of merits of using cooperative learning. For instance, Harmer (1991) points out that working cooperation increases the amount of student talking time and gives opportunities to students in order to use the target language to communicate with each other.

Among researches conducted in our country concerning cooperative learning, Seid (2012) and Endalew (2009) worth mentioning. Seid in his study on "Effects of Cooperative Learning on Reading Comprehension Achievement in EFL and Social Skill of Students" by using quantitative research methodology using different instruments for pre and post tests, questionnaire, observation and interview. Finally, he concluded that cooperative learning, which is studentcentered learning method, helps to improve students' reading comprehension achievement as it creates a more friendly and supportive learning environment within which students have the opportunity to listen to one another, ask questions and clarifying issues. Students get the opportunity to learn and practice social skills such as taking turns, asking, giving and receiving help, active listening, participating equally, etc. Due to these, it is found that in cooperative learning environment, students cooperate with each other to maximize their own and each other's learning.

Furthermore, Endalew (2009) also conducted a research on factors unconstructively affecting students' learning and has found out that there is students' lack of awareness to gain experience from each other, teachers' lack of plan on CLL in EFL classroom, sex-oriented discrimination among students and others. From the two local studies, neither of these studies has assessed EFL learners' attitude towards cooperative language learning. In addition, as the researchers have observed through several years' of English language teaching experience in the school, the students have less motivation to work cooperatively in EFL classroom. Therefore, the current 
Zeleke Teshome Lucha et alo,

study is focused to investigate why students have less motivation to work cooperatively in EFL classroom and to bridge the gap by assessing their attitude towards cooperative language learning in their actual classroom. The objective of the study was to investigate EFL learners' attitude towards cooperative language learning in EFL classroom.

\section{MATERIALS AND METHODS}

As indicated in section one, this study was intended to find out the attitude of EFL learners' towards cooperative language learning method. For this purpose, therefore, a descriptive survey research design was chosen to describe the nature of the existing conditions. This means, the study tried to describe the reason why students demotivate to work cooperatively in CLL and the students' attitudes towards CLL in EFL classes. Descriptive survey study design was chosen because it allowed the researchers to describe the current situation of the subjects of the study.

\section{Subjects of the Study}

The subjects of the study were grade eleven students and English language teachers who have been learning and teaching at Limmu preparatory school to obtain reliable information. The respondents of the study were 70 (48 males and 22 females) grade eleven students who were selected randomly from Limu Preparatory School for the questionnaire and interview questions.

The two English language teachers who have been teaching in grade eleven of Limu Preparatory School that is found in East Wollega Administrative Zone were also the subjects. Teachers were not focal points of the study but meant to serve as the cross checking purpose of students' response. Both teachers were included for classroom observation and interviews in the study for crosschecking the students' responses. There were two teachers respondents and both of them were degree holders in English language teaching. This shows that the required level of education is maintained. Regarding teachers' experiences, one teacher has five years of work experience in teaching and the second teacher has eighteen years. A number of students in each section were sixty-seventy who were assigned to each section and totally there were 482 students in grade 11 of the school selected.

\section{Sampling Techniques}

Sampling is the process of selecting a number of study units from a defined study population. It enables the researcher to study a relatively small number of units (subjects) from the target population (Sarantakos, 1993). For this study, the researchers used simple random sampling for students and purposive sampling techniques for teacher respondents to gather the necessary information. In random sampling techniques, each member of the sampled population has an equal chance of being selected. In purposive sampling, on the other hand, the goal is to select subjects that are likely to be information-rich with respect to the purpose of the study. In order to make the sampling techniques used clear for sampling schools, grade levels, sections, teachers and students are presented separately one after the other as follows:

Limu Preparatory school was selected based on convenience sampling and the researchers' familiarity to
Sci. Technol. Arts Res. J., July-Sep 2015, 4(3): 240-252

this research area. Convenience sampling is the most common sampling method in educational studies at present time as it allows the researchers to have easy access to particular research area (Mujis, 2004). The school is found in Oromia region and located in West of East Wollega Zone at the distance of $466 \mathrm{~km}$ from Addis Ababa and $138 \mathrm{~km}$ from Nekemte.

Grade eleven was selected through purposive sampling. In purposive sampling, the researcher aimed at selecting the subjects who are relevant to the study to get in-depth information. The rationale behind choosing this grade level is the availability for the researcher to observe while teaching.

Generally, there were seven grade eleven sections at this academic year. Therefore, to select the sections to be observed, the names of each section were written on pieces of papers, and then the papers were scrolled, mixed up and drawn by lottery method. The pieces of papers which had the names of the three sections occurring on the papers were taken as selected classroom for observations. Thus, three sections taught by two teachers were observed six times different lessons for example third conditionals and different phrasal verbs based on their willingness.

The study includes two English language teachers of grade eleven in the school as the subject of the study for the interview and classroom observation on voluntary bases. The total numbers of students assigned in to grade eleven seven sections in 2014 academic year were 482 . Of these, ten students from each section who were totally $70(15 \%)$ students were randomly selected to fill the questionnaire and two students from each section who were totally $14(2 \%)$ students were selected randomly for interview questions in the study.

\section{Instruments of Data Collection}

In order to gather valuable information for the study, the researchers used interviews for both teachers and students, and a combination of open-ended and closeended items in the questionnaire for students.

\section{Interviews}

In this study, in addition to classroom observation, semi-structured interview was administered to obtain the necessary information by actually talking to the participants of the study. Semi-structured interview was used because it allowed some elaborations in the questions and answers (Dornyei, 2007). In semistructured interview, more of the questions are openended and there is usually be flexibility in the order in which groups of questions are asked (Kayrooz and Trevitt, 2006).

The researchers used a semi-structured interview as the students could have the confidence to interact and express their own opinions on the issues. The interview questions were developed by the researchers from the concept in the review of related literature. For this study, the purpose of the interview was asking students to share what they feel towards cooperative language learning in EFL classroom. It is also to obtain information relevant to CLL method, to comment the benefits of CLL for the students and factors that influence while they were learning in cooperative learning, and to express student's feelings about the participation of their group members, 
Zeleke Teshome Lucha et al.,

etc. With this regard, Selinger and Shohamy (1989) point out that the use of interview as a data collection instrument permits a level of in-depth information, free response and flexibility that cannot be obtained by other procedures. To do this, ten (10) items of interview questions were delivered to the students for interview. Then, the interview which took forty-fifty minutes was conducted for only one day in one of the classrooms in their school on April 22, 2014.

Teachers' semi-structured interview was used by assuming that they would be able to talk about the subject in detail, and complex questions and issues can be raised and discussed. This tool was also used to collect qualitative data by setting up the interview that allowed teachers to talk about their opinions on cooperative language learning. In this research, the main purpose of the teachers' interview was to find out the opinion of the English language teachers in implementing cooperative language learning method in EFL classroom. For this reason, eleven (11) items of interview questions were prepared by the researchers from the review of related literature and administered on May 4, 2014 at the school in one of the classrooms for about half an hour. Before conducting the interview, with teachers, the purpose of the interview was explained by the researcher that it was for the research purpose.

\section{Questionnaire}

In this study, questionnaire was used to gather both quantitative and qualitative data. The popularity of questionnaire is due to the fact that it is relatively easy to construct, and capable of gathering a large amount of information quickly in a form that is readily accessible (Dornyei, 2007). Questionnaire is also flexible in the sense that a wide range of information can be collected. A questionnaire is an economical and convenient to describe the existing conditions of characters. Selinger and Shohamy (1989) as cited in Lakachew (2003) state that a questionnaire is widely used in research to get information about certain conditions and practices, particularly to collect data on phenomena which are not easily observed, such as attitudes and self-concepts. Thus, the researcher used an attitude likert-type scale to measure the degree of the attitudes of the students towards CLL method. An attitude likert-type scale is a crude measuring device, consisting of a number of statements to which the respondents must express their degree of agreement or disagreement (Evdokia, 1996). The students' questionnaire consists of both open-ended and close-ended items to measure the students' attitudes towards CLL. The questionnaire was developed by the researchers from the review of related literature before administering to the respondents. Every possible effort has been made to avoid ambiguities in designing the questionnaire. Besides, all effort has been made to make the questionnaire as comprehensive and representatives as possible to the major principle of cooperative language learning method and to the basic research objectives and questions.

The questionnaire was developed with twenty (20) items thirteen favorable (positively) and seven unfavorable (negatively) worded likert-scale statements where individuals respond to statements between the extremes on the continuum that represent their attitude by responding to scales ranged from "strongly agree" to "strongly disagree" to each statement. Favorable
Sci. Technol. Arts Res. J., July-Sep 2015, 4(3): 240-252

statements are those which are in line with the principles of cooperative language learning, and unfavorable statements represent the negative implication in cooperative language learning. Nevertheless, both were intended for the same purpose that means to get information about EFL learners' attitudes towards cooperative language learning method. In this case, for positively worded items, "strongly agree" had a score of ' 5 ' and "strongly disagree" had a score of ' 1 '. However, the negatively worded items and those items which had negative implication were reversed in scoring.

The rating scale constructed for this study was the lickert technique of scale construction. As Karavas (1996) point out likert type scale (or method of summated ratings) is the most widely used method scale construction because of its relative ease of construction, its use of fewer statistical assumptions, and the fact that, in contrast to other scaling techniques, no judges are required. Karava (1996) says unlike the other two very common techniques of attitude scale construction (Thurstone and Guttman), likert scale does not use experts to judge which statements are most appropriate for the attitude scale. Besides, it does not use a laborious procedure to select the most appropriate items for inclusions in the scale.

The attitude questions were given five scales that show the level of agreement of students to the principles and techniques of CLL method. These are 'strongly agree' (5), 'agree' (4), 'undecided' (3), 'disagree' (2), and 'strongly disagree' (1). Thus, the respondents' scores of 3.5 and above indicated better and favorable attitude towards CL, scores between 3.5 and 2.5 indicated neutral attitude while scores below 2.5 are considered as unfavorable attitude. In general seventy copies of questionnaire were distributed, eleven (11) of them were rejected as they lacked clarity, specificity and representativeness and five (5) of them were not returned back but fifty-four of the distributed question papers were collected.

\section{Data Organization and Analysis}

Data obtained through observation, students' and teachers' interviews and students' questionnaire were analyzed in terms of their respective similarities and differences. The qualitative data obtained through classroom observations were analyzed along with openended questionnaire using words. Similarly, the data collected from students' close-ended questionnaire were analyzed quantitatively by using frequency percentages and complemented by the data gathered by the means of qualitative methods. Thus, the data gathered qualitatively and quantitatively were analyzed using thematic and inductive analysis. While analyzing the data, the researchers integrated issues generated through instruments and induced the data for interpretation to reach on conclusions and each analyzed items was coded in a way that it was appropriate for statistical calculations.

Quantitative data obtained from the respondents were organized and tallied according to their thematic group manually. Then the frequency and percentage were computed using tables, and interpreted quantitatively based on numerical value. The analysis of attitude questions was made by valuing the items as 'Strongly agree'=5, 'Agree'=4, 'undecided'=3, 'Disagree'=2, 'Strongly disagree' $=1$. Accordingly, respondents were asked to tick the appropriate response to indicate how far they agree or disagree with each item referring to CLL 
Zeleke Teshome Lucha et alo,

principles. Thus, the items with ' 5 ' mean score would imply the most favorable attitude of the respondents and the items with mean score ' 1 ' would be the least favorable attitude implying strong disagreement of the respondents to the item.

However, data obtained through observation checklist by "yes/no" response followed by detailed notes on each item, students' and teachers' interview responses, and students' responses to open-ended items in the questionnaire were analyzed qualitatively by describing explicitly in words. So, both quantitative and qualitative descriptions were analyzed thematically by using qualitative and quantitative research method.

\section{RESULTS AND DISCUSSIONS}

This section deals with the discussion of the results obtained through classroom observation, interviews, and questionnaire. The data collected through interviews, and questionnaire were tabulated, analyzed and discussed
Sci. Technol. Arts Res. J., July-Sep 2015, 4(3): 240-252

thematically by linking similar ideas together. The questionnaire was categorized into four groups according to their similarities with common central theme. These are the importance of CLL in promoting students' EFL skills, the students' roles in CLL, the students' response to teachers' roles in CLL classroom, and the students' attitude towards CLL.

\section{The Importance of CLL in Promoting Students' EFL Skills}

EFL students' attitude of CLL in terms of its importance in promoting their language skills was analyzed using descriptive statistics as follows. All the data gathered through interviews and questionnaire were analyzed one after the other by linking them together according to their similarities. In this way, the students' questionnaire was analyzed first and the data from the interview was analyzed as shown in the following consecutive table.

Table 1: The importance of CLL in promoting students' EFL skills

\begin{tabular}{|c|c|c|c|c|c|c|c|c|c|}
\hline \multirow[b]{2}{*}{ No } & \multirow[b]{2}{*}{ Items } & \multirow[b]{2}{*}{$\begin{array}{c}\% \text { or } \\
\text { frequency }\end{array}$} & \multicolumn{5}{|c|}{ Alternatives } & \multirow[b]{2}{*}{ Total } & \multirow[b]{2}{*}{ Mean } \\
\hline & & & $\begin{array}{l}\text { Strongly } \\
\text { agree (5) }\end{array}$ & $\begin{array}{l}\text { Agree } \\
\text { (4) }\end{array}$ & $\begin{array}{c}\text { Undecided } \\
\text { (3) }\end{array}$ & $\begin{array}{l}\text { Disagree } \\
\text { (2) }\end{array}$ & $\begin{array}{c}\text { Strongly } \\
\text { disagree } \\
\text { (1) }\end{array}$ & & \\
\hline \multirow{3}{*}{1.1} & $\begin{array}{l}\text { CLL method enhances } \\
\text { students' willingness to }\end{array}$ & $\mathrm{F}$ & 32 & 28 & 6 & 3 & 1 & 70 & \multirow{3}{*}{4.2} \\
\hline & take risk for their own & & & & & & & & \\
\hline & $\begin{array}{l}\text { and group members' } \\
\text { learning. }\end{array}$ & $\%$ & 46 & 40 & 8.6 & 4 & 1.4 & 100 & \\
\hline \multirow{2}{*}{1.2} & CLL develops students' & $\mathrm{F}$ & 42 & 22 & 3 & 2 & 1 & 70 & \multirow{2}{*}{4.4} \\
\hline & extended practice. & $\%$ & 60 & 31 & 4.2 & 3 & 1.4 & 100 & \\
\hline \multirow{2}{*}{1.3} & Students learn best when & $\mathrm{F}$ & 22 & 32 & 10 & 4 & 2 & 70 & \multirow{2}{*}{3.9} \\
\hline & by their teacher. & $\%$ & 31. & 46 & 14 & 6 & 2.8 & 100 & \\
\hline \multirow{2}{*}{1.4} & CLL develops students' & $\mathrm{F}$ & 34 & 20 & 12 & 3 & 1 & 70 & \multirow{2}{*}{4.1} \\
\hline & $\begin{array}{l}\text { Interpersonal and social } \\
\text { skills. }\end{array}$ & $\%$ & 49 & 29 & 17 & 4 & 1.4 & 100 & \\
\hline \multirow{2}{*}{1.5} & Students learn best when & $\mathrm{F}$ & 28 & 32 & 6 & 3 & 1 & 70 & \multirow{2}{*}{4.1} \\
\hline & $\begin{array}{l}\text { they work with others in } \\
\text { pairs and groups. }\end{array}$ & $\%$ & 40 & 46 & 8.5 & 4 & 1.4 & 100 & \\
\hline
\end{tabular}

As can be seen from table 1 item 1.1 dealing with CLL method enhances students' willingness to take risk for their own and group member's learning. $48 \%$ of the respondents "strongly agreed" and $40 \%$ "agreed" that CLL method enhances students' willingness to take risk for their own and group members' learning. $4.2 \%$ of the respondents "disagreed" $1.4 \%$ "strongly disagreed" and only $8.6 \%$ of the respondents undecided. When this is described in terms of mean, the mean value is 4.2 which is in the favorable attitude with regard to the scale. This shows that CLL enhances students' willingness to take risk for their own learning and others.

According to Crandall (1999, P.233), as cited in Seid (2012), the importance of using cooperative learning in second and foreign language classroom is gaining acceptance in multitude of language learning classrooms, mainly because of its contribution to improving supportive and expanding opportunities for learners to use the language. Cooperative language creates more positive effective climate in the classroom. It also individualizes instruction and raises students' motivation. Copola (2007) also states that cooperative learning promotes positive social behavior which is necessary for all students; it enhances self-determination and self- efficiency which are crucial for student development. Accordingly five items were posed to students to obtain information on the extent to which students understand the concept of the importance of CLL in promoting their EFL skills. In response to the item, "CLL develops students' confidence through extended practice", $60 \%$ of the respondents "strongly agreed" and $31.4 \%$ "agreed". Only $2.8 \%$ "disagreed" and $1.4 \%$ of them "strongly disagreed". $4.2 \%$ undecided to the item. The mean value for this item is 4.4 which is above the average. This tells us that CLL develops students' confidence through extended practice of the language. Accordingly, Seid (2012) stated in his study that the longer cooperative group exists, the greater the social support they will provide for each other's success, and the more influence members will have over each other.

Regarding item 1.3 which was intended to elicit information on whether students learn best when taught as a whole class by their teacher or not. $31.4 \%$ "strongly agreed" and $45.7 \%$ "agreed". $14 \%$ of the respondents undecided and only $5.7 \%$ "disagreed" whereas $2.8 \%$ "strongly disagreed". The mean value of the responses for 
Zeleke Teshome Lucha et al.,

this item is 3.9. This shows that students' attitude is more favorable towards teacher-fronted instruction rather than cooperative learning. From this we can understand that though the statement has negative implication with CLL principles, students believed that teacher-fronted instruction is as important as cooperative language learning. Most students believed that teacher is the only person who knows everything. Chips (1993) states that cooperative learning gives students opportunities to learn from one another rather than receiving instruction from the teacher alone. Appropriate cooperative tasks also stimulate students to higher levels of thinking, preparing for academic learning and testing.

To the statement, "CLL develops students' interpersonal and social skills", $48.5 \%$ of the respondents "strongly agreed" and $28.5 \%$ "agreed" that CLL develops students' interpersonal and social skills. $4.2 \%$ "disagreed" and $1.4 \%$ "strongly disagreed". $17.1 \%$ of the respondents were undecided. When this is described in terms of mean, the mean value of the responses for this item is 4.1 which indicated that students have favorable attitude towards CLL as it develops their interpersonal and social skills. Regarding this Terwel (2003) revealed that cooperative learning was designed to develop social skills and acceptable social attitudes in students and to improve social relations within and between groups.

Regarding item 1.5 which reads, "students learn best when they work with others in pairs and groups", $40 \%$ of the respondents "strongly agreed" and $45.7 \%$ "agreed" while $4.2 \%$ "disagreed" and $1.4 \%$ of the respondents "strongly disagreed". $8.5 \%$ of them were unable to decide about their preference. The mean score for this response is 4.1. Thus, it is clear that the majority of the students have shown their positive attitude towards learning in their pairs and groups. However, the data from classroom observation tell us that majority of the students were not actively participated in their cooperative learning.

In general, from the above points, it is possible to say that EFL learners have positive attitude towards cooperative language learning principles in line with the importance of it in promoting their EFL skills. However, from the classroom observation, it is possible to say students have less motivation in cooperative work.

Moreover, responses from open- ended questions revealed that CLL is a method of language learning in which students learned in groups to attain common goals through cooperation with each other as it gives them the opportunities to practice language skills more than the case of teacher-centered instruction. In addition to this, classrooms in which the teacher largely controlled the learning may result in short-term learning gains, whereas in cooperative classroom in which positive interdependence was a key factor consistently results in more learners' achievement over a longer period of time. Except $22.8 \%$ of the students the remaining $77.1 \%$ of the respondents showed their preference to CLL method as it is more favorable way for their learning than teachercentered instruction.

In addition to the questionnaire, some students were asked some related questions like "how CL maximizes their own and others' learning", "the role of CLL in promoting their EFL skills" and "whether CLL enhances motivation and reduces students' stress" through
Sci. Technol. Arts Res. J., July-Sep 2015, 4(3): 240-252

interview. Accordingly, the data from the interview has shown that students who participate in cooperative learning have higher levels of self-esteem and greater motivation to learn, they have stronger sense that classmates have positive regard for one another. Cooperative learning maximizing students own and each other's learning in that they are linked with group members in such a way those they cannot succeed unless their group members do.

Similarly, teachers were also interviewed "how CLL improves their students' EFL skills" and "to explain important aspects of using formal and informal CL group". They said that learning in groups increases communication and social skills such as presentation, leadership, organization and problem solving. They also said that cooperative learning gives more opportunities to the students to get involved in a meaningful interaction in an active-learning circumstances, promote higher achievement for students, enhances motivation, and in general, it improves social and psychological skills.

Concerning the important aspects of using formal and informal cooperative learning group, the data from the respondents has shown that formal cooperative learning group lasts from one class period to several weeks or to several class sessions to complete a specific task or assignment. It ensures that students are actively involved in the intellectual work organizing materials, explaining it, summarizing it, and integrating it in to existing conceptual structures. On the other hand, informal cooperative learning groups are temporarily, ad-hoc groups that last only for one discussion, whose purpose is to focus students' attention on the material to be learned. The data from the questionnaire and interviews have shown that students have a favorable attitude towards cooperative learning in promoting students' EFL skills.

\section{The Students' Roles in CLL}

This section is intended to examine the way students perceive their roles in EFL classroom. Thus, all the data collected through observation, interview, and questionnaire were analyzed under this sub-title all together one after the other so as to bring similar ideas at one place. In this way, the data from questionnaire, interview, and observation were analyzed in their order. Accordingly, the following table contains four items reflecting EFL learners' attitude towards CLL in terms of their roles in language learning classroom.

According to the table, item 2.1, students were asked whether CLL provides more opportunities for them to practice language or not. $42.8 \%$ students responded that "strongly agreed" whereas $45.7 \%$ of respondents "agreed" to the statement. $4.6 \%$ of them "disagreed or strongly disagreed". The mean value for this response is 4.2 which is in the average scale of favorable attitude towards the statement. This shows that students believe working cooperatively in EFL class provides more opportunities for them to practice the language.

Regarding item 2.2 which deals with in CLL method roles shared to group members, $25.7 \%$ of them "strongly agreed" and $37.1 \%$ "agreed" that in cooperative learning students work in small groups or teams, sharing the work and helping one another to complete group activities. 30\% of the respondents were unable to decide their preference and $7.5 \%$ of them "disagreed or strongly disagreed". The 
Zeleke Teshome Lucha et al.,

mean value for this response is 3.8 . So it can be said that students have positive attitude towards CLL in relation to roles shared among group members. Regarding the item students evaluating their own learning in CLL, majority of the respondents have positive attitude towards it. $47 \%$ of them "agreed" and $40.1 \%$ "strongly agreed". Only $5.6 \%$ of
Sci. Technol. Arts Res. J., July-Sep 2015, 4(3): 240-252

the respondents "disagreed or strongly disagreed". $7.1 \%$ were undecided. When the mean is computed, it is 3.8 which is above the average. From this, we can deduce that students evaluate their group performance for better improvement in cooperative learning.

Table 2: Items related to students' roles in CLL (students response)

\begin{tabular}{|c|c|c|c|c|c|c|c|c|c|}
\hline \multirow[b]{2}{*}{ No } & \multirow[b]{2}{*}{ Items } & \multicolumn{6}{|c|}{ Responses } & \multirow[b]{2}{*}{ Total } & \multirow[b]{2}{*}{ Mean } \\
\hline & & $\begin{array}{c}\% \\
\text { and } \\
\text { frequency }\end{array}$ & $\begin{array}{l}\text { Strongly } \\
\text { agree(5) }\end{array}$ & $\begin{array}{l}\text { Agree } \\
\text { (4) }\end{array}$ & $\begin{array}{l}\text { Undecided } \\
\text { (3) }\end{array}$ & $\begin{array}{c}\text { Disagree } \\
\text { (2) }\end{array}$ & $\begin{array}{l}\text { Strongly } \\
\text { disagree } \\
\text { (1) }\end{array}$ & & \\
\hline \multirow[b]{2}{*}{2.1} & CLL provides more & $f$ & 30 & 32 & 5 & 2 & 1 & 70 & \multirow{2}{*}{4.2} \\
\hline & $\begin{array}{l}\text { opportunities for students } \\
\text { to practice language. }\end{array}$ & $\%$ & 43 & 46 & 7 & 2.8 & 1.8 & 100 & \\
\hline \multirow{2}{*}{2.2} & \multirow{2}{*}{$\begin{array}{l}\text { It is impossible in large } \\
\text { class of students to } \\
\text { organize your learning. }\end{array}$} & $f$ & 18 & 26 & 2 & 4 & 1 & 70 & \multirow{2}{*}{3.8} \\
\hline & & $\%$ & 26 & 37 & 30 & 5.7 & 1.8 & 100 & \\
\hline \multirow{2}{*}{2.3} & \multirow{2}{*}{$\begin{array}{l}\text { Students have the role of } \\
\text { evaluating their own } \\
\text { learning in CLL. }\end{array}$} & $f$ & 28 & 33 & 5 & 2 & 2 & 70 & \multirow{2}{*}{4.1} \\
\hline & & $\%$ & 40 & 47 & 7 & 2.8 & 2.8 & 100 & \\
\hline \multirow{2}{*}{2.4} & \multirow{2}{*}{$\begin{array}{l}\text { CLL enhances greater } \\
\text { responsibilities for students }\end{array}$} & $f$ & 42 & 22 & 2 & 3 & 1 & 70 & \multirow{2}{*}{4.4} \\
\hline & & $\%$ & 60 & 31 & 3 & 4.2 & 1.8 & 100 & \\
\hline
\end{tabular}

Regarding item $2.4,60 \%$ of the students "strongly agreed" and $31.4 \%$ "agreed" that CLL enhances greater responsibilities for students. $6 \%$ of them were "disagreed or strongly disagreed" and only 2.85 of the respondents were undecided to the statement. When the mean value is computed, it is 4.4. Accordingly, it can be said that majority of the students perceived and have positive attitude towards CLL as it enhances greater responsibilities of students.

From the above points, it is possible to say that EFL learners have positive attitude towards CLL in relation with items related to students' roles in cooperative learning. In addition to this, responses from open-ended questions revealed that students have the roles of contributing to the group's efforts, encouraging their fellow group members to contribute, keeping each other on task, working towards their shared goals, treating each other with care and respect. Hence, students nowadays play a role as a teacher besides learners to teach their friends and they can learn a lot from each other. Accordingly, except $38.6 \%$ students, the remaining $61.4 \%$ of the respondents explained their roles in CLL class.

In semi- structured interview session, some students explained their opinion and experiences in cooperative learning concerning the meaning of cooperative learning for them, whether they learn English cooperatively and learn best when they work with other group or not.

Most of the students said almost the same thing that it is the instructional use of small groups so that students work together to maximize their own and each other's learning. Others said it is a set of processes which helps people interact together in order to accomplish a specific goal or develop an end product which is content specific. Thus, each member of the group is responsible for learning what is taught and helping group learning. Students learn best when they work in their groups in that it promotes students' learning and academic achievement, increasing student retention, enhancing student satisfaction with their learning experience, helping students develop skills in oral communication, develop social skills, promoting student self-esteem, and helping to promote positive image of self and others.

Furthermore, the students were also asked whether they take responsibilities for their own learning and how decisions are made in their groups. Hence, the data from interview has shown that each member of the group is accountable for completing his or her part of the work, and direct their own learning through developing the skills of planning, motivating and evaluating their own learning. Cooperative group learning requires each student in the group to develop a sense of personal responsibility to learn and to help the rest of the group to learn.

The result from the classroom observation regarding how students report group work and play the role of group leaders shows that the teachers were attempting to elicit the students in class activities. However, in all observed classes, the groups formed were based on randomly arranged seats as usual setting arrangements. There was no group formed on heterogeneous basis. For example, most of the groups in the observed classes were all males or females. Students' classroom exercises were provided by their teachers for already formed groups based on their seating places. Students' attempts on tasks were reported or answered by volunteer students. In most cases, no students were made to report group work and no group formed on heterogeneous bases was observed. In two out of six observed classes, the students were made to report the group work.

Regarding students' active participation in group discussion and working cooperatively for themselves and each other's success, the classroom observation revealed that they were not actively participating and making hot discussion when teachers attempt to give them group activities. Teachers were observed trying to involve students to participate in the group and to comment on answers to questions. Students were observed waiting for what the teacher was saying and writing. Most students were sitting idly and looking here and there even not taking the note when the teacher attempted to let them. The researchers can deduced from this, that students 
Zeleke Teshome Lucha et alo,

hadn't been exposed to cooperative work by themselves rather than waiting from the teacher, and students may have the problem of language proficiency to interact with the target language. As a result, from the above discussion the researchers can realized that students were not willing to work cooperatively for themselves as well as for each other's success.

Students' Response to Teachers' Roles in CLL

Under this sub-title, the researchers intended to examine the way students perceive the roles of teachers in cooperative learning classroom.
Sci. Technol. Arts Res. J., July-Sep 2015, 4(3): 240-252

As can be deduced from table 3 , most students $(42.8 \%)$ showed their strong agreement, and $35.7 \%$ of them showed their agreement to whether or not the teacher decides on the size of cooperative learning group. Only $6 \%$ of the respondents showed their disagreement or strong disagreement and $15.7 \%$ undecided to the statement. The mean value for this item is 4.1 . This indicates that students perceive that it is the duty of the teacher to decide the size of the group learning.

Table 3: Students' response to Teachers' roles in CLL

\begin{tabular}{|c|c|c|c|c|c|c|c|c|c|}
\hline \multirow[b]{2}{*}{ No } & \multirow[b]{2}{*}{ Items } & \multirow[b]{2}{*}{$\begin{array}{c}\% \\
\text { and } \\
\text { Frequency }\end{array}$} & \multicolumn{5}{|c|}{ Responses } & \multirow[b]{2}{*}{ Total } & \multirow[b]{2}{*}{ Mean } \\
\hline & & & $\begin{array}{l}\text { Agree } \\
\text { (5) }\end{array}$ & $\begin{array}{l}\text { Agree } \\
\text { (4) }\end{array}$ & $\begin{array}{l}\text { Undecided } \\
\text { (3) }\end{array}$ & $\begin{array}{l}\text { Disagree } \\
\quad(2)\end{array}$ & $\begin{array}{l}\text { Strongly } \\
\text { disagree } \\
\text { (1) }\end{array}$ & & \\
\hline \multirow{2}{*}{3.1} & \multirow{2}{*}{$\begin{array}{l}\text { The teacher decides on the } \\
\text { size of groups. }\end{array}$} & $F$ & 30 & 25 & 11 & 3 & 1 & 70 & \multirow[b]{2}{*}{4.1} \\
\hline & & $\%$ & 49 & 36 & 16 & 4.2 & 1.8 & 100 & \\
\hline \multirow{2}{*}{3.2} & $\begin{array}{l}\text { The role of the teacher in EFL } \\
\text { classroom is to impart }\end{array}$ & $F$ & 26 & 30 & 8 & 3 & 3 & 70 & \multirow[b]{2}{*}{4} \\
\hline & $\begin{array}{l}\text { knowledge through different } \\
\text { activities. }\end{array}$ & $\%$ & 37 & 43 & 11 & 4.2 & 4.2 & 100 & \\
\hline \multirow{2}{*}{3.3} & \multirow{2}{*}{ 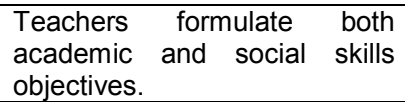 } & $\mathrm{F}$ & 28 & 24 & 12 & 4 & 2 & 70 & \multirow[b]{2}{*}{4} \\
\hline & & $\%$ & 40 & 34 & 17 & 5.7 & 2.8 & 100 & \\
\hline \multirow{2}{*}{3.4} & \multirow{2}{*}{$\begin{array}{l}\text { In CLL teacher is facilitator of } \\
\text { the cooperative group. }\end{array}$} & $F$ & 50 & 16 & 4 & - & - & 70 & \multirow[b]{2}{*}{4.6} \\
\hline & & $\%$ & 71 & 23 & 5.7 & - & - & 100 & \\
\hline
\end{tabular}

To the statement, "the role of the teacher in EFL classroom is to impart knowledge through different activities", $37.1 \%$ of the respondents strongly agreed and $42.8 \%$ agreed that teacher is to impart knowledge through different activities in EFL classroom. 8.4\% disagreed or strongly disagreed. The rest $11.4 \%$ of the respondents undecided to the statement. When the mean value is computed for this item, it is 4 and this indicate that students believed that teacher is the only person who knows everything. However, instead of being lecturers in traditional techniques, teachers in cooperative learning are facilitators, prompters, motivators, etc. Cohen (1972) suggests that cooperative learning teachers become accustomed to supportive supervision rather than traditional direct supervision. And a teacher who uses cooperative learning techniques might seem to have less work than one who uses traditional ones (James C. Flowers et al.1994).

Regarding item 3.3, which reads "teachers formulate both academic and social skills objectives", $34.2 \%$ of the respondents "agreed" and $40 \%$ "strongly agreed" to the statement. $17.1 \%$ were unable to decide their preference to the statement. Only $8.5 \%$ "disagreed or strongly disagreed". Accordingly, in response to this item, students with the mean score of 4.0 were aware that teachers in cooperative learning formulate both academic and social skills objectives.

The next statement, item 3.4, states "in cooperative language learning, a teacher is a facilitator of the cooperative group". Concerning this, $71.4 \%$ of the respondents strongly agreed and $22.8 \%$ "agreed" to the statement. Only $5.7 \%$ undecided and the mean value with this score is 4.6 . This shows that a large number of students aware that teachers in CLL are facilitators and monitors. Concerning this, Johnson et al. (2008), states that while conducting the lesson, teachers monitor each learning group and intervene when needed to improve task work and teamwork.

Furthermore, concerning the teachers' roles in CLL, responses from open-ended questions revealed that teachers have the roles of (1) making pre instructional decisions like deciding on the size of groups (2) explaining the instructional tasks and cooperative structure such as structuring individual accountability (3) monitoring students' learning and intervening to provide assistance in completing the task carefully or using the target interpersonal and group skills effectively (4) assessing students' learning and helping students process how well their groups functioned. For instance, ensuring students carefully discuss how effectively they worked together (i.e process the effectiveness of their learning groups) and have students make a plan for better improvement.

Moreover, in the interview sessions, teachers were asked questions about what CLL method for them and their roles in language learning class. Then, two of the teacher respondents have shown their ideas almost in the same way. Accordingly, cooperative learning is a way for students to learn essential interpersonal life skills and to develop the ability to work collaboratively. In addition, the response in the interview showed that cooperative learning is a method that students work in small groups or teams, sharing the work and helping one another in language class. Similarly, they suggested that their roles in language learning class are, the responsibilities of planning lesson activities and evaluation, grouping students, physical placement of students, presenting and explaining the task to the students, monitoring group activities and intervening when necessary, helping students with social skills and evaluating students. 
Zeleke Teshome Lucha et alo,

Regarding cooperative based groups, teacher respondents said that teachers have the role of forming heterogeneous groups of four or five, schedule the time when they will regularly meet, create specific agenda with concrete tasks that provide a routine for base groups to follow when they meet, ensure the five basic elements of effective cooperative groups are implemented and have students periodically process the effectiveness of their bas groups. Similarly, monitoring the learning groups creates individual accountability; whenever teacher observes a group, members tend to feel accountable to be constructive members. The teachers also asked how they organize their students in English classes and how they decide on the size of the groups. One teacher said that he organize the group randomly without considering their sex as well as their learning achievement level and deciding the group size because of their sitting arrangements.

The other teacher responded that, grouping was dynamic and sometimes formed by the teacher and sometimes by themselves with different sex and achievement level. This difference in achievement level or sex made them happy as it enabled them to see new friends and share different experiences from multidimensional angles. What the researchers can deduced from the above point is that both teachers never
Sci. Technol. Arts Res. J., July-Sep 2015, 4(3): 240-252

decide the size of the group and no mixed (heterogeneous) groupings were done.

\section{Students' Attitudes towards CLL}

This section was intended to examine the way students perceive CLL in EFL class. As can be seen from the table 4 , item $4.1,81.4 \%$ of the respondents "disagreed or strongly disagreed" that group work activities are bored and waste a lot of valuable teaching-learning time. $9.9 \%$ of the respondents "agreed or strongly agreed" and $8.5 \%$ of the respondents were unable to decide their preference. The mean value for this item is 1.8 which is below the average of the scale. This revealed that the greater majority of the respondents have positive attitude and perceived that group work does not waste the valuable time of learning -teaching and not bored rather it motivates. Concerning this, Kagan (1995), cited in Seid (2012) states that cooperative learning was considered time consuming to teach materials in a cooperative way although more students might have learned and retained better of the materials. This might be true, especially in the beginning when cooperative learning was new to teacher and students. In addition, cooperative learning lessons may be failed, if teachers only put students into groups without instruction or paying attention to positive interdependence or individual accountability.

Table 4: Students' responses related to their attitude towards cooperative language learning

\begin{tabular}{|c|c|c|c|c|c|c|c|c|c|}
\hline No & Items & $\begin{array}{c}\% \text { and } \\
\text { frequency }\end{array}$ & $\begin{array}{l}\text { Strongly } \\
\text { Agree(5) }\end{array}$ & $\begin{array}{c}\text { Agree } \\
(4)\end{array}$ & $\begin{array}{c}\text { Undecided } \\
(3)\end{array}$ & $\begin{array}{c}\text { Disagree } \\
(2)\end{array}$ & $\begin{array}{c}\text { Strongly } \\
\text { Disagree(1) }\end{array}$ & Total & Mean \\
\hline \multirow{2}{*}{4.1} & \multirow{2}{*}{$\begin{array}{l}\text { Group work activities are } \\
\text { boring and waste a lot of } \\
\text { valuable teaching and } \\
\text { learning time. }\end{array}$} & $\mathrm{F}$ & 4 & 3 & 6 & 22 & 35 & 70 & \\
\hline & & $\%$ & 5.7 & 4.2 & 8.5 & 31 & 50 & 100 & 1.8 \\
\hline \multirow[b]{2}{*}{4.2} & \multirow{2}{*}{$\begin{array}{l}\text { Group interaction } \\
\text { motivates students in EFL } \\
\text { classroom. }\end{array}$} & $\mathrm{F}$ & 36 & 27 & 4 & 3 & - & 70 & \multirow[b]{2}{*}{4.3} \\
\hline & & $\%$ & 51 & 39 & 5.7 & 4 & - & 100 & \\
\hline \multirow{2}{*}{4.3} & $\begin{array}{l}\text { CLL gives students' } \\
\text { opportunities to learn from }\end{array}$ & $\mathrm{F}$ & 48 & 16 & 5 & - & 1 & 70 & \multirow[b]{2}{*}{4.5} \\
\hline & $\begin{array}{l}\text { one another rather than } \\
\text { receiving from the teacher. }\end{array}$ & $\%$ & 69 & 23 & 7 & - & 1.4 & 100 & \\
\hline \multirow[b]{2}{*}{4.4} & $\begin{array}{l}\text { Teaching learners to take } \\
\text { responsibility for their own }\end{array}$ & $\mathrm{F}$ & - & 3 & 6 & 21 & 40 & 70 & \multirow[b]{2}{*}{1.6} \\
\hline & $\begin{array}{l}\text { learning is futile since } \\
\text { learners are not used to } \\
\text { such an approach. }\end{array}$ & $\%$ & - & 4 & 9 & 30 & 57 & 100 & \\
\hline \multirow{2}{*}{4.5} & $\begin{array}{lcc}\text { Students' } & \text { access } & \text { to } \\
\text { practicing } & \text { EFL } & \text { for }\end{array}$ & $F$ & 33 & 28 & 7 & 1 & 1 & 70 & \multirow[b]{2}{*}{4.3} \\
\hline & $\begin{array}{l}\text { communication purpose is } \\
\text { best promoted in CLL. }\end{array}$ & $\%$ & 47 & 40 & 10 & 1.4 & 1.4 & 100 & \\
\hline \multirow[b]{2}{*}{4.6} & $\begin{array}{l}\text { Cooperative work activities } \\
\text { have little use since it is }\end{array}$ & $F$ & 1 & 5 & 4 & 22 & 38 & 70 & \multirow[b]{2}{*}{1.7} \\
\hline & $\begin{array}{l}\text { very difficult for the teacher } \\
\text { to monitor the students' } \\
\text { performance. }\end{array}$ & $\%$ & 1.4 & 7.1 & 5.7 & 31 & 54 & 100 & \\
\hline \multirow{2}{*}{4.7} & It is impossible in large & $f$ & 2 & 2 & 5 & 25 & 36 & 70 & \multirow{2}{*}{1.7} \\
\hline & $\begin{array}{l}\text { classes of students to } \\
\text { organize your learning. }\end{array}$ & $\%$ & 2.8 & 2.8 & 7 & 36 & 51 & 100 & \\
\hline
\end{tabular}

Similarly, in response to 4.2 , which reads, "group interaction motivates students in EFL classroom", 51.4\% of the respondents strongly agreed while $38.5 \%$ agreed. Only $4.2 \%$ disagreed and $5.7 \%$ of them undecided to the statement. When the mean value is computed, it is 4.3 which are in the average of favorable attitude. This could be an indication of CLL method motivates students' selflearning. Accordingly, Crandall (1999) stated that cooperative learning creates a more positive affective climate in the classroom; it also individualizes instruction and rise student motivation.

Regarding item $4.3,68.5 \%$ of the students showed their strong agreement while $22.8 \%$ showed their agreement to CLL method that gives students' opportunities to learn from one another rather than receiving from the teacher. Only $7.1 \%$ of the students' undecided to the statement and the mean value for this 
Zeleke Teshome Lucha et al.,

response is 4.5 which are in the average of favorable attitude scale. This indicated that students believe that CLL gives students' opportunities to learn from one another rather than receiving from their teacher. In addition to this, Chips (1993), cited in Seid (2012) revealed that cooperative learning gives students opportunities to learn from one another rather than receiving instruction from the teacher alone. He said that appropriate cooperative tasks stimulate students to higher levels of thinking, preparing them for academic learning and testing.

The next statement item, 4.4 which was intended to identify whether or not teaching learners to take responsibility for their own learning is futile, $57.1 \%$ of the students "strongly disagreed" and $30 \%$ "disagreed" to the statement. Only $4.2 \%$ of the students "agreed" and $8.5 \%$ undecided. The mean value for this item is $1.6 \%$ which is below the average and this shows that the students believe that teaching them to take responsibility for their own learning is crucial and they have favorable attitude towards the statement. Regarding this, Johnson and Johnson (2009), states the importance of teaching learners to take responsibility for their own learning is no one can 'hitchhike' on the work of others, and it requires each pupil in the group to develop a sense of personal responsibility to learn and to help the rest of the group.

In response to item 4.5, "students' access to practicing EFL for communication purpose is best promoted in CLL", $47.1 \%$ of the students showed their "strong agreement" while $40 \%$ "agreed" to the statement. $10 \%$ of the students unable to decide their agreement and only $2.8 \%$ "disagreed or strongly disagreed". The mean value of this item is 4.3 which shows favorable attitude towards the statement. From this, we can deduce that students improve their communication skills through extended practice of English in CLL. Coming to the next item 4.6, which reads cooperative work activities have little use since it is very difficult for the teacher to monitor the students' performance. $54.2 \%$ of the students showed their "strong disagreement" and $31.4 \%$ "disagreed" to the statement cooperative work activities have little use since it is very difficult for the teachers to monitor the students' performance. The rest $8.5 \%$ of the respondents strongly agreed while $5.7 \%$ undecided. The mean value of this item is 1.7 which is below the average scale and that shows students are disagreed to the statement and they think that teacher can monitor students in cooperative learning classroom. Relating to this, Jacob and Hall, (2007) stated that it is difficult for teachers who are familiar with traditional roles such as lecturers or performers to get use to cooperative learning. This indicated that unless teachers understand the way to implementing cooperative structure carefully and decide some rules relating to discipline or marks before hand, teachers may feel confused to get students' attention when they are working in group, and to make participations not make noise.

Regarding item $4.7,51.4 \%$ of the students "strongly disagreed" while $35.7 \%$ "disagreed" to the statement it is impossible in large classes of the students to organize their learning. $7.1 \%$ indicated that the respondents are unable to decide their preference. Only, 5.6\% "agreed or strongly agreed". When mean is computed for this item, it is $1.7 \%$ which is below the average scale and that shows students disagreed to the statement. From this, we can
Sci. Technol. Arts Res. J., July-Sep 2015, 4(3): 240-252

understand that, it is possible in large classes of students to organize students in cooperative learning.

Furthermore, the responses from open-ended questions concerning items related to students' attitudes towards CLL method showed that except few students, the remaining $85 \%$ of the students showed positive attitude towards cooperative language learning method. Majority of the students showed their positive attitude that CLL is one of the EFL learning method in which students are learned in groups to attain common goals through cooperation with each other as it gives them the opportunities to practice language skills more than teacher-centered instruction. Similarly, the data revealed that in cooperative learning, students work cooperatively can know how to cooperate with others, they can learn others' learning skills, attitude, personality, and they can see their point of views other than their own. On the other hand, few students showed their unfavorable attitude that cooperative learning is time consuming to teach materials and students can make a noise during discussion. In most situations, cooperative group has some members who do not want to work with others, they will keep silence or some students would like to control their team mates to talk all the time.

The next item was intended to investigate whether or not students actively participate during cooperative language learning. Thus, the data obtained from the respondents showed that $42 \%$ of the respondents were actively participating during cooperative language learning and they also mentioned the benefits from their active participation. Thus, CLL gives opportunities to learn from one another rather than receiving from the teacher alone, and students develop their language skills through group interaction. Furthermore, students responded that interacting in group discussion promotes individual accountability and foreign language communication as it gives them the opportunities to practice language skills. It is a method for organizing learning in which students working with their peers towards a shared academic goal rather than competing or working separately from their peers.

On the other hand, the remaining $58 \%$ of the respondents showed as they don't actively participate during cooperative learning. The data revealed that students are unfamiliar with cooperative learning and may not accept this style of learning or they may be unsure of the techniques or possibly even they think that it is time consuming. In addition, students make noise and teachers may feel confused to get students' attention when they are working in groups and as a result the class became loss of control and bored. Similarly, teachers unable to implement the cooperative structures (positive interdependence and individual accountability) carefully, organizing cooperative learning groups based on the students' sex and heterogeneity. Regarding this, Johnson and Johnson (1999) mentioned that if teachers only put students in to group without instruction or paying attention to positive interdependence or individual accountability cooperative learning may be failed. They also revealed that instructors should pay attention to the potential barriers to group effectiveness such as group maturity, motivation, losses due to perceived in equality, lack of sufficient heterogeneity, uncritically giving one's dominant response and lack of teamwork sills. 
Zeleke Teshome Lucha et alo,

The results from interview session also confirmed that students lack of experience (unfamiliar) with cooperative language learning style, lack of monitoring and intervening to provide assistance in completing the task successfully, lack of structuring positive interdependence and individual accountability, lack of assessing students' learning and feedback from their teacher, mixed (heterogeneity) of the groups, sitting arrangements of the students and all these results in students became demotivated and hinders them not to learn cooperatively in EFL classroom. Regarding this, Johnson et al. (2008) state that teachers explain the academic assignment to students, structure positive interdependence and individual accountability, explain the behaviors (i. e social skills) students are expected to use, also teach the concepts and strategies required to complete the assignment during pre- instructional decisions. Johnson also explained that while conducting the lesson, teachers monitor each learning group and intervene when needed to improve the task work and team work.

Monitoring the learning groups creates individual accountability. Whenever a teacher observes a group, members tend to feel accountable to be constructive members. Teachers also assessing students' learning and helping students process how well their groups functioned by ensuring students carefully discussions, how effectively they worked together (i.e process the effectiveness of their learning groups), and have students make a plan for better improvement .According to Johnsons (2008), the assessment of students achievements highlights individual and group accountability (i.e how well each student performed) and indicates whether the group achieved its goals. The group feedback received during group processing is aimed at improving the use of social skills and is a form of individual accountability.

Students were also asked how their attitudes towards learning EFL can have their own effect up on their English language learning. The data obtained from the students' interview showed that the students' prior knowledge of English language determines their learning and there are many stimulants which lead to positive or negative attitude of individuals. The respondents said that high achievers are relatively familiar to interaction during the lesson and they have positive attitude towards learning language cooperatively. Whereas low achievers are generally passive during small group work and didn't have interest to learn in cooperative group. This shows that they have negative attitude towards cooperative language learning.

The students' prior level of achievements likely plays an important role in determining achievement in the future. The students' achievements prior to the implementation of group learning in the classroom serve as a significant predictor of their achievement in the future both directly or indirectly by affecting their motivation to learn. Different researchers claimed that high motivation and positive attitude towards a second language and its community help second language learning. Accordingly, Jones (1984) states that learning is related to attitudes; what is learned may depend on the attitude of the learner. However, students' lack of motivation in class participation can be taken as the symptom of their unfavorable attitude to the given context. Data from the teachers' interview session revealed that students' attitude toward the teacher, language learning, the school and various
Sci. Technol. Arts Res. J., July-Sep 2015, 4(3): 240-252

subjects, and specifically towards cooperative learning are primarily important in the learning situation.

Similarly, Chamber(1999) cited in Abebaw (2011), also stated that students with highly positive social orientation towards working in groups with peers in the learning process ; such as willingness to share information sources, to exchange ideas with peers, and to make discussions collectively preferred cooperative learning class more than a competitive social orientation. The classroom also observed whether or not the students' sitting arrangement is suitable for group discussion and for the teachers to observe each group process and the availability of learning materials such as text book. The data showed that most of the students were sitting in three or four group members in rows and it was available for teachers to observe each groups learning. Majority of the students have one English text book on each table and that shows the materials are available for the students' cooperative learning.

\section{CONCLUSIONS}

The purpose of this study was to investigate EFL learners' attitude towards cooperative language learning method. To accomplish this objective, different data gathering instruments classroom observation, interviews, and open-ended and close- ended questionnaire were used. The participants of the study were two English language teachers and seventy of grade eleven sample students at Limu preparatory school which is found in East Wollega Zone. Data obtained from respondents were analyzed through qualitative research method. Therefore, this section deals with the major findings, conclusions, and recommendations.

As clearly discussed in the previous section, the response of students on the importance of CLL in promoting their EFL skills showed that almost all students have shown their positive attitude of the principles of CLL. Thus, students feel cooperative language learning as it improves supportive and expanding opportunities for learners to use the language and it creates a more positive climate in the classroom. Regarding students' view of CLL develops students' confidence through extended practice, the majority of the students with the mean value 4.4 perceived the favorable instructional outlook. This indicated, students aware that the longer cooperative group exists, the greater the social support they will provide for each other, the more committed they will be each other's' success and the more influence members will have each other's.

As the findings of the study showed on the importance of CLL method in promoting students EFL skills, almost all students have shown their positive attitude towards the principles of CLL method. Accordingly, students perceive cooperative language learning as it improves supportive and expanding opportunities for learners to use the language and it creates a more positive affective climate in the classroom. In response to the respondents, the students aware that the longer cooperative group exists, the greater the social support they will provide for each other.

As the response of the respondents shown, CLL gives opportunities for students to learn from one another rather than receiving the teacher alone, develop their language skills through group interaction, and a method for 
Zeleke Teshome Lucha et al.,

organizing learning in which students are working with their peers towards a shared academic goals. The findings also revealed that CLL method is the instructional use of small groups so that students' work together to maximize their own and each other's learning. In general, it is possible to say that EFL learners have positive attitude towards CLL method in line with its importance in promoting their EFL skills.

As indicated in the analysis of the findings, majority of the students showed their favorable attitude that CLL develops students' interpersonal and social skills, and it improves social relations within and between groups. Respondents also have shown their positive outlook that in cooperative learning, students work in small groups, sharing the work and helping one another to complete group activities. As the results of the study showed us, students have negative attitude towards the idea of cooperative learning activities are bored and waste a lot of valuable teaching and learning time. This shows that students perceive as cooperative learning motivates students in group discussions and maximizes their own and each other's learning.

As the findings of the study showed, the students' prior knowledge of English language determines their learning. Thus, high achievers are relatively familiar to interaction during the lesson and they have positive attitude towards learning the language cooperatively whereas low achievers are generally passive and have negative attitude towards learning the language.

As indicated in the analysis of the findings, many factors mentioned by the respondents hinder the students' active participation in cooperative learning classroom. Accordingly, students' lack of experience (unfamiliar) with CLL method, students' prior knowledge of the English language (the problem of students' language proficiency to interact with the target language), teachers unable to structure positive interdependence and individual accountability carefully, lack of organizing learning groups based on heterogeneous base groups, lack of monitoring and intervening from the teacher to provide assistance in completing the task successfully, lack of assessing students' learning and fed back from their teacher, and sitting arrangements of the students made the students demotivated and hinders them not to participate actively during cooperative learning.

The findings of the study revealed that students have the roles contributing to the groups' efforts, encouraging their fellow group members to contribute, working towards their shred goals, keeping each other's on task, treating each other's with care and respect to learn from each other. Students have the role of directing their own learning through developing the skills of planning, monitoring and evaluating their own learning.

\section{Conflict of Interest}

Conflict of interest none declared.

\section{Acknowledgments}

First and for most, we would like to express our sincere gratitude to Gida Ayana Woreda Education Bureau and the Director of Limu Secondary School for their unreserved guidance and support throughout the course of the study. We have sincere appreciation for their follow-up during our difficulty moments. Next, we
Sci. Technol. Arts Res. J., July-Sep 2015, 4(3): 240-252

would like to thank students of Limu Preparatory School who scarified their precious time in filling the questionnaire and answered interview questions for the study. Our thanks are also due to English language teachers of Limu preparatory school as they collaborated with us by attending the interviews and letting us observe their classrooms during the teaching and learning process. Without their assistant and participation, this study would not have been successful.

\section{REFERENCES}

Abebaw Andargie (2011). EFL Learners' Attitude towards Group Work : The Case of High and Low Achievers. Addis Ababa University: Addis Ababa. http://etd.aau.edu.et/dspace/handle/123456789/4841

Apple, M.T. (2006). Language Learning Theories and Cooperative Learning Techniques in the EFL Classroom. Doshisha Students in Language and Culture. Doshisha Studies in Language and Culture 9(2): 277-301.

Brown, H.D. (1991). Teaching by Principles an Interactive Approach to Language Proficiency. Upper Saddle Rivers, NJ USA; Prentice Hall Regents.

Byrne, D. (1987). Techniques for Classroom Interaction. London: Longman.

Carpini, M.D. (2009). Enhancing Cooperative Learning in TESOL Teachers Education. ELT Journal 63(1): 42-50.

Charness, M.A. kipper man, J. Rabow .J, and Radcliffevasile, (1994). Learning Through Discussion ( $3^{\text {rd }}$ ed.). SAGE Publications.

Chips, B. (1993). Using Cooperative Learning at Secondary Level. In: D.D .Hoit (Ed.) Cooperative Learning. Washington, DC: Center of Applied Linguistics and ERIC Clearing House on Language and Linguistics.

Crandall, J. (1999). Cooperative Language Learning and Affective Factors. In: Arnold (Ed.), Affective in Language Learning (pp. 226-245). Cambridge: Cambridge University Press.

Christison, M.A. (1994). Cooperative learning in the EFL classroom. In T. Kral (Ed.), Teacher development: Making the right moves. Selected articles from the English Teaching Forum 1989-1993 (pp. 139-147). Washington D.C.: English Language Programs Division.

Cohen, E.G. (1994). Designing Group Work Strategies for the Heterogeneous Classroom. New York; Teachers College Press.

Cohen, E.G, Brody. C.M and Shevin, M.S. (2004).Teaching Cooperative Learning, The Challenge for Teachers Education New York; State University of New York press.

Coppola,C. (2007). Cooperative Learning Groups in ESL Social Studies. Retrieved, November10, (2013), from http:// www.ohioteachered. Coppola.doc.

Deutsch, M. (1949). A Theory of Cooperation and Competition. Human Relation 2:129-152.

Deutsch, M. (1962). Cooperation and Trust: Some Theoretical Notes. in M. Jones (Ed.) Nebraska Symposium on Motivation. Lincoln, NE: University of Nebraska Press. Retrieved March 6, 2014, from http://www.Co.operation.Org/home/introduct---

Dornyei, Z. (1997). Psychological Processes in Cooperative Language Learning: Group Dynamics and Motivation. Modern Language Journal 81: 482-493. 


\section{Zeleke Teshome Lucha et alo,}

Dornyei, Z. (2007). Research Methods in Applied Linguistics Quantitative, Qualitative and Mixed Methodologies. Oxford: Oxford University Press.

Endalew Fufa (2009). Factors Negatively Affecting Students' Cooperative Learning. Adama; Adama University.

Evdokia, K. D.(1996). Using Attitude Scales to Investigate Teachers' Attitudes to the Communicative Approach. ELT Journal 50(3). Oxford University Press.

Fehling, S. (2008). Cooperative Learning in EFL Classroom. Retrieved December 18, 2013, from http://www.iaie.org/downloadfehling.pdf

Harmer, J. (1991). The Practice of English Language Teaching. London.

Jacob, G. M., and Hall, S. (2007). Implementing Cooperative Learning: Methodology in Language teaching. New York: Cambridge University Press.

James, C, Flowers and John. M. Ritz, (1994). Cooperative Learning in Technology Education. Virginia Council on Technology Teacher Education.

Johnson, D.W, and Johnson, R .T. (1989). Cooperation and Competition: Theory Research. Edina, MN: Introduction Book Company.

Johnson, D.W, and Johnson, R .T. (1994). Learning Together and Alone; Cooperative, Competitive, and individualistic Learning $\left(4^{\text {th }} \mathrm{e} d\right)$. Boston; Allyn and Bacon.

Johnson, R.W.(1999). Learning Together and Cooperative, Competitive and an Individualistic Learning ( $5^{\text {th }}$ ed). Engel woud cliffs $\mathrm{NJ}$; prentice Hall.

Johnson, D. W. and Johnson, R. T.(1999). Learning Together and Alone: Cooperative, Competitive, and Individualistic Learning (5th ed). Boston: Allyn andBacon.

Johnson, D.W., Johnson, R.T., and Holubec, E. (2008). Cooperation in Classroom (8th Ed.). Edina, MN: Interaction Book Company.

Jolliffe,, W. (2007). Cooperative Learning in the Classroom; Putting in to Practice, Paul Chapman Publication; London ECTY ISP.

Kagan, S. (1985). We can Talk-Cooperative Learning in the Elementary Classroom. Washington, DC (ERIC Document Production, No. ED, 382035).ales from the Real World. Australia: Allen and Unwin.

Kessler, C.C. (1992). Cooperative Language Learning teachers Resources. Prentice-Ha Inc .

Mc Groarty, M. (1989). Cooperative Learning and Second Language Acquisition. In D.D.Holt (ED.), Cooperative Learning. Washington, DC: Centre of Applied Linguistics and ERIC Clearinghouse on Language and Linguistics.

Meng, J. (2010). Cooperative Learning Method in Practice of English Reading and Speaking. Journals of Language Teaching and Research 1(5). 701-705.
Sci. Technol. Arts Res. J., July-Sep 2015, 4(3): 240-252

MoE. (2008). General Education Quality Implementation Program, FDRE, Addis Ababa: MOE.

Mujis, D. (2004). Doing Quantitative Research in Education. London: Sage Publications Ltd.

Nunan, D. (1992). Task-based Language Teaching. Cambridge: Cambridge University press.

Nunan, D. (1992). Collaborative Language Learning and Teaching Boston: Heine and Heine Publisher.

Oxford, R.L. (1997). Cooperative Learning, Collaborative Learning and Interaction: Three Communicative Strands in the Language Classroom. The Modern Language Journal 81(4): L443-445.

Palmer, G. Peters and Streetman, R. (2003). Cooperative Learning. In: M. Orey (ED.) Emerging perspectives on Learning, Teaching, and Technology. Retrieved Nov 3, 2013,from http// projects, Coe.uga.edu/Inex.

Richards, J.C. and Rodgers, T.S. (2001). Approaches and Methods and Language Teaching $\left(2^{\text {nd }}\right.$ ed). Cambridge: Cambridge University press.

Robson, C. (1993). Real World Research: A resource for Social Sciences and Practitioner - researchers. Australia: Black Well Publishing.

Sarantakos, S. (1993). Social Research. Australia: Macmillan Australia Pvt. Ltd.

Seid Mohammed (2012). Effects of Cooperative Learning on Reading Comprehension Achievement in EFL and Social Skills. Addis Ababa University: Addis Ababa.

Sharan, S. (1990). The Group Investigation Approach to Cooperative Learning: Theoretical Foundations. Perspectives on Small group Learning: Theory and Practice. Canada: Rubicon pub, Inc.

Slavin, R.E. (1987). Cooperative Learning and the Cooperative School. Educational Leadership 45(3): 7-13.

Slavin, R.E. (1990). Comprehensive Cooperative Learning Models: Embedding Cooperative Learning in the Curriculum and the School. In: S. Sharon (Ed.), Cooperative Learning .Theory and practice. New York: Praeger.

Slavin, R.E. (1991). Synthesis of Research on Cooperative Learning. Education Leadership 48(5): 71-77.

Slavin, R.E. (1994). A practical Guide to Cooperative Learning. Boston: Allyn and Bacon.

Trowel, J. (2003). Cooperative Learning in Secondary Education: A curriculum Perspective. In: R.M. Gillis and A.F. Ashman (Eds.), Cooperative Learning. The Social and Intellectual Outcomes of Learning in Groups (54-68), London and New York: Rutledge Flamer Taylor and Francis Group.

Zhang,Y. (2010). Cooperative Learning and Foreign Language Learning and Teaching. Journal of Language Teaching and Researching 1(1): 81-83. 